\title{
Limiting the State's Police Power: Judicial Reaction to John Stuart Mill
}

\author{
$[T]$ he only purpose for which power can be rightfully exercised \\ over any member of a civilised community, against his will, is \\ to prevent harm to others. His own good, either physical or \\ moral, is not a sufficient warrant. ${ }^{1}$
}

John Stuart Mill's essay On Liberty ${ }^{2}$ considers in great detail the nature of that individual conduct which the state is justified in controlling and beyond which the state should not interfere. The basic element of Mill's libertarian philosophy with respect to this aspect of individual liberty is that an individual's own welfare, physical or moral, is not sufficient ground in itself to justify the state's interference with the individual's conduct. The attitude of American courts toward the use of this criterion as a basis for proscribing state regulation of individual conduct is the primary concern of this comment. ${ }^{3}$

1 J.S. MIIL, On Liberty, in MIIL, UTILITARIANISM, ImBERTY, AND REPRESENTATIVE GOVERNMENT 95-96 (Am. ed. 1951) [hereinafter cited as MIrL]. The full paragraph from which the headnote is taken reads:

The object of this Essay is to assert one very simple principle, as entitled to govern absolutely the dealings of society with the individual in the way of compulsion and control, whether the means used be physical force in the form of legal penalties, or the moral coercion of public opinion. That principle is, that the sole end for which mankind are warranted, individually or collectively, in interfering with the liberty of action of any of their number, is self-protection. That the only purpose for which power can be rightfully exercised over any member of a civilised community, against his will, is to prevent harm to others. His own good, either physical or moral, is not a sufficient warrant. He cannot rightfully be compelled to do or forbear because it will be better for him to do so, because it will make him happier, because, in the opinion of others, to do so would be wise, or even right. These are good reasons for remonstrating with him, or reasoning with him, or persuading him, or entreating him, but not for compelling him, or visiting him with any evil in case he do otherwise. To justify that, the conduct from which it is desired to deter him must be calculated to produce evil to some one else. The only part of the conduct of any one, for which he is amenable to society, is that which concerns others. In the part which merely concerns himself, his independence is, of right, absolute. Over himself, over his own body and mind, the individual is sovereign.

The sections of Mill's essay most relevant to the discussion in this comment are Chapter IV, Of the Limits to the Authority of Society over the Individual, and Chapter V, Applications. MmL at 176, 201.

2 Id.

8 Mill was born in 1806 and published his essay On Liberty in 1859. Obviously Mill himself did not influence the writers of the Constitution. However, Mill did elaborate on many of the concepts of political freedom which had evolved in the century before him. It is in the sense that Mill was one of the most eloquent spokesmen of these concepts that this comment speaks of Mill's philosophy or, more specifically, Mill's 
One underlying difficulty in pursuing the inquiry that will be attempted here should be noted at the outset. Despite the extraordinary position of $O n$ Liberty as a document which is regarded by many people of differing political persuasions as a statement of fundamental political truth-witness the claim to Mill's support by both Lord Devlin and H. L. A. Hart in their dialogue on the enforcement of morality ${ }^{4}$ -Mill's principle, especially in its explicit form, generally does not enjoy high visibility in judicial decisions. One explanation for the low visibility of Mill's influence in the case law is that such influence probably had an impact on the legislative process, thus effectively screening out those measures most obnoxious to Mill's principle and to the legislators' concern with individual freedom. A second explanation lies in the decline of substantive due process and the consequent narrowing of judicial willingness to limit the state's exercise of the police power. ${ }^{5}$ A court's failure to limit legislation clearly inconsistent with Mill's formula may therefore be attributable to its reluctance to act at all rather than to its rejection of Mill sub silentio. Thirdly, since there is no specific constitutional provision embodying Mill's principle-notwithstanding two recent Supreme Court decisions which might be read broadly to suggest a constitutionally derived criterion akin to Mill's ${ }^{8}$ courts may be reticent to strike down such legislation in the absence of a more explicit constitutional mandate. In short, implicit or explicit recognition of Mill's principle in judicial decisions may not accurately reflect its continuing vitality as a limitation on governmental action.

It should also be noted that the apparent simplicity of Mill's proposition may disappear when it is applied in particular circumstances. The distinction between conduct affecting others and conduct affecting only one's self is essentially one of degree. ${ }^{7}$ Mill himself, for instance, puzzled over the application of his criterion to the keeping of a gambling-

criterion for testing the legitimacy of state interference with individual conduct. It is also important to recognize that it is Mill's political theories, and not his economic theories, that are under consideration.

For discussion of the political thought contemporaneous with the writing of the Constitution, see generally A.H. Kelty, Where Constrtuxional LIBERTY GaMe From (1954); C. Mullet, Fundamental Law and the American Revolution, 1770-1776 (1966); C. Rosstrer, The Political Thought of the American Revolution (1963); Pound, The Development of Constitutional Guarantees of Liberty, 20 Notre DAME LAw. 183, 347 (1945).

4 Sir Patrick Devlin, The Enforcement of Morals 9-13 (1965); H.L.A. Hart, The Morality of the Criminal Law (1965); H.L.A. Hart, Law, Liberty and Morality (1963).

5 See text at notes 100-3 infra.

6 Stanley v. Georgia, 394 U.S. 557 (1969), discussed in text at notes 54-60 infra; Griswold v. Connecticut, 381 U.S. 479 (1965), discussed in text at notes 96-98 infra.

7 See text at notes $70-77$ infra. 
house in light of his conclusion that gambling, considered alone, affects only the individual. ${ }^{8}$ Despite the difficulties which are inherent in most attempts to draw distinctions suggested by Mill's principle, it nevertheless raises important questions about many areas of legislation. Compulsory medical, ${ }^{9}$ and mental ${ }^{10}$ treatment, the prohibition of the consumption of allegedly harmful substances, ${ }^{11}$ participation in air raid drills, ${ }^{12}$ regulation of sexual mores, ${ }^{13}$ industrial safety measures, ${ }^{14}$ and compulsory insurance ${ }^{15}$ are but a few examples. This discussion will focus on three representative areas: intoxicating liquor, motorcycle helmets, and the possession of obscene material. Liquor regulation provides an his-

8 MIIII at 207-9.

9 Note, Compulsory Medical Treatment: The State's Interest Re-evaluated, 51 MinN. L. REv. 293 (1966). It should be noted, however, that much compulsory medical treatment is aimed at protection of the community and not the treatment of the individual. Quarantine and vaccination laws have been upheld as protection against contagious diseases. Jacobson v. Massachusetts, 197 U.S. 11 (1905); Moore v. Draper, 57 So. 2d 648 (Fla. 1952).

In water fluoridation cases the state's special role of parens patriae for children has been invoked, Chapman v. Shreveport, 225 La. 859, 74 So. $2 d 142$ (1954), as has the fact that fluoridated water benefits the general public and is not actually compulsory for the individual, Paduano v. New York, 45 Misc. 2d 718, 257 N.Y.S.2d 531 (Sup. Ct. 1965). One difficulty with the fuoridation problem is that it cannot be feasibly individualized so as to except those who do not desire it. See also Kraus v. City of Cleveland, 163 Ohio St. 559, 127 N.E.2d 609 (1955); Note, Legal Aspects of the Fluoridation of Public Drinking W'ater, 23 Geo. WASH. L. Rev. 343 (1955); Comment, Fluoridation of Public Water Supplies, 3 Hastrngs L.J. 123 (1952).

The doctrine of parens patriae is invoked for the care of minors. Jehovah's Witnesses v. King County Hosp., 278 F. Supp. 488 (W.D. Wash. 1967), aff'd per curiam, 390 U.S. 598 (1968); People v. Labrenz, 411 Ill. 618, 104 N.E.2d 769, cert. denied, 344 U.S. 824 (1952) (blood transfusion for minor); In re Vasko, 238 App. Div. 128, 263 N.Y.S. 552 (1933) (surgical removal of child's eye), noted in 68 U.S.L. REv. 117 (1934). It should be noted that Mill specifically recognizes the state's special interest in the care and protection of minors. Mill at 96.

Perhaps the most direct confrontation between Mill's principle and compulsory medical treatment is presented by the administration of blood transfusions to Jehovah's Witnesses. See notes 88-91 infra and accompanying text.

10 Even though Mill speaks of "human beings in the maturity of their faculties," MirL at 96, the problem of the harmlessly insane is pertinent. See Comment, Liberty and Required Mental Health Treatment, 114 U. PA. L. Rev. 1067 (1966). See, e.g., Wills v. Attorney General, 201 F.2d 556 (10th Cir. 1953); Lake v. Cameron, 364 F.2d 657 (D.C. Cir. 1966); Mayock v. Martin, 157 Conn. 56, 245 A.2d 574 (1968), discussed in Comment, Society's Right to Protect an Individual from Himself, 2 ConN. L. REv. 150 (1969).

11 Intoxicating liquor and drugs are examples. For discussion of the former, see text accompanying notes 26-42 infra; of the latter, see text accompanying notes 62-64 infra.

12 People v. Peck, 7 N.Y.2d 76, 163 N.E.2d 866, 195 N.Y.S.2d 637, cert. denied, 364 U.S. 662 (1959) (upholding compulsory participation against religious objections).

13 See text accompanying notes 78-85 infra.

14 See, e.g., 3 Wis. AdM. Code $\$ \S 3.07(19), 6.05(3)$ and Wis. STAT. $\$ 101.28$ (1965).

15 Compulsory liability insurance is aimed at the protection of prospective plaintiffs and does not raise the issue involved in this comment. However, Social Security does raise the issue. 
torical perspective on the issue, and the other two areas of inquiry reveal contrasting answers to questions raised in the context of contemporary opinion. Before examining these objects of state regulation, it is appropriate to consider the basis of state regulation of private conduct.

\section{The State's Police Power}

Most state regulation of individual conduct is founded on the police power, the exercise of which is justified by the interest of the state in achieving a workable degree of social organization and harmony. ${ }^{16}$ Historically, the police power was not widely exercised, but with the expansion of government into new areas, the maxim Sic utere tuo ut alienum non laedas was relied upon to uphold the increasing reach of legislation. ${ }^{17}$ The emphasis on this maxim gradually shifted from a positive basis for the police power to a negative limitation on its scope, the latter supposedly following by implication from the former. ${ }^{18}$

This maxim remains in current usage, ${ }^{19}$ but it has been increasingly replaced by a series of maxims and counter-maxims operating at various levels of abstraction in the legal process. At the basic level it is often stated that the exercise of the state's police power must have a reasonable relationship to the public safety, health, morals, or general welfare, both as to the goals of the legislation and as to the means used to achieve those goals. ${ }^{20}$ However, this is qualified by the notion that the legislature has wide discretion in determining what constitutes the public safety, health, morals, and general welfare, and also what constitutes a reasonable measure to carry out its purposes. ${ }^{21}$ In turn this

16 For an extensive early discussion, see 2 T.M. CoOLEY, TREATISE ON THE ConstrTutional Limitations 1223 (8th ed. 1927) [hereinafter cited as 2 Cooley].

172 CoOLEY at 1225, 124I; Smead, Sic Utere Tuo Ut Alienum Non Laedas: A Basis of the State Police Power, 21 CoRnerr L.Q. 276 (1936). Roughly translated the phrase means: Use your own property so as not to injure that of another. BLAck's LAW DicrionARY (4th ed. 1951).

18 Smead, supra note 17.

19 See, e.g., American Motorcycle Ass'n v. Davids, 11 Mich. App. 351, 354, 158 N.W.2d 72, 74 (1968) (voided statute requiring motorcyclists to wear protective helmets); State v. Warren, 252 N.C. 690, 694, 114 S.E.2d 660, 664 (1960) (upheld statute requiring licensing of real estate brokers and salesmen).

20 See, e.g., Alves v. Justice Court, $148 \mathrm{Cal}$. App. 2d 419, 422, 306 P.2d 601, 603 (Ct. App. 1957) (voided curfew ordinance); Florida Citrus Comm'n v. Golden Gift, Inc., 91 So. 2d 657, 660 (Fla. 1956) (voided requirement on labeling of orange juice); Kirtley v. State, 227 Ind. 175, 181, 84 N.E.2d 712, 714 (1949) (voided law prohibiting ticket sales at prices above standard price); People v. Bunis, 9 N.Y.2d 1, 4, 172 N.E.2d 273, 274, 210 N.Y.S.2d 505,507 (1961) (voided law prohibiting sale of written material from which title page had been removed); Appeal of Lord, $368 \mathrm{~Pa}$. 121, 129-30, 81 A.2d 533, 537 (1951) (abuse of discretion by zoning board in refusing to issue permit). 2 CooleY at 1231 .

21 See, e.g., People v. Aguiar, 257 Cal. App. 2d 597, 603, 606, 65 Cal. Rptr. 171, 1745, 
is qualified by the principle of judicial review that the courts must not abdicate their responsibility in passing upon such legislation. ${ }^{22}$ Needless to say, this duality may in practice give the courts considerable leeway in delineating the scope of the police power. Ultimately, the question of whether and how Mill's criterion affects judicial review of legislation is to be answered more by the substance of what the courts have done than by the rhetoric used.

In considering the issues, a distinction must be made between legislation $^{23}$ that is brought to bear on a person other than the party to be benefited and legislation that bears directly on the person benefited. For example, statutes requiring automobile manufacturers and dealers to equip all cars with seat belts are within the scope of the police power since the general public and not the manufacturer or dealer is sought to be protected.24 However, a statute requiring all persons to wear seat belts while driving in private vehicles benefits only the person who is restricted by the statute, and the validity of such legislation falls within the issue posed here. This distinction should be kept in mind in considering the great expansion of health and welfare legislation of the past century. While the definition of public health, safety, and welfare has broadened greatly during this period, the legislation in question has with few exceptions regulated the activity of employers, manufacturers, sellers, carriers, and landlords, and not the activity of employees, consumers, purchasers, passengers, and tenants for whose

177 (Ct. App. 1968), cert. denied, 393 U.S. 970 (1968) (upheld prohibition of the possession of marijuana); Levy v. State, 250 La. 25, 192 So. 2d 193, 195 (La. Cir. Ct. App. 1966), (upheld statute denying illegitimate children the right to recover for wrongful death of their mothex); rev'd, 391 U.S. 68 (1968); Stepp v. State, 202 Miss. 725, 731, 32 So. 2d 447, 448 (1947), suggestion of error overruled, 202 Miss. 725, 33 So. 2d 307 (1948) (upheld prohibition of possession of intoxicating liquors); Ex parte Fowler, 85 Okl. Crim. 64, 73-74, 184 P.2d 814, 819 (1947) (upheld statute permitting involuntary confinement for venereal disease). 2 COOLEX at $1228,1231$.

22 See, e.g., American Motorcycle Ass'n v. Davids, 11 Mich. App. 351, 358, 158 N.W.2d 72, 76 (1968) (voided requirement of protective helmets for motorcyclists); State v. Williams, 146 N.C. $618,624,61$ S.E. 61, 63 (1908) (voided prohibition of possession of intoxicating liquors); State v. Gilman, 33 W. Va. 146, 148, 10 S.E. 283, 284 (1889) (voided prohibition of possession of intoxicating liquors). E. FREUND, POLICE POWER 13-16 (1904).

23 While the term "legislation" will be frequently used to describe government action, this comment is not confined to state action through legislation but encompasses government action through judicial and administrative orders as well. However, the area of private civil action is not included. Thus the designation of failure to use seat belts as contributory negligence in some jurisdictions does not fall within the scope of this comment.

24 While it is true that the buyer is thus compelled to pay for seat belts, he is not liable to a fine for nonuse. This is more market regulation than regulation of conduct. In another vein, the nonuse of seatbelts as a basis for contributory negligence in tort cases is not a regulation of conduct but a guideline for deciding equities as between the private parties. 
benefit the legislation was passed. ${ }^{25}$ Even with the vast reach of welfare legislation, most of this legislation would not contradict Mill's precepts.

\section{Judicial Limitations on the Police Power}

\section{A. An Historical Process: Intoxicating Liquors}

One traditional concern of the state police power has been the regulation of intoxicating liquors. Prohibition or regulation of the sale or manufacture for sale of intoxicating liquor falls within the scope of restricting the conduct of the few for the protection of the general public; however, statutes affecting the manufacture or possession of liquor for one's own use are not of the same character. Early commentators stated that the police power did not extend to the regulation of a person becoming intoxicated in private. ${ }^{26}$ There was strong state judicial support for such a thesis at that time, ${ }^{27}$ and Mill was extensively quoted by at least one court. ${ }^{28}$ Before quoting Mill, the court in Commonwealth $v$. Campbell ${ }^{29}$ paraphrased Mill's principle:

25 For a discussion of this legislation, see Brown, Police Power-Legislation for Health and Personal Safety, 42 HARv. L. REv. 866 (1929) (especially the summary at 896-7).

26 E. Freund, Police Power 484 (1904):

It is ... significant that the policy of prohibition stops short of dealing with the private act of consumption.

C. Tiedemann, Limitations of Police Power 151, 302 (1886):

It cannot be made a legal wrong for one to become intoxicated in the privacy of his room, when the limitation upon his means does not make drunkenness an extravagance. ... If a man displays his drunkenness on the public thoroughfares to the annoyance and inconvenience of the public, he can be punished therefore. But if he choose to degrade himself in his own home or apartments by intoxication, he commits no offense against the public, and is consequently not subject to police regulation.

Professor Freund in his general discussion of liquor control states:

If [protection from temptation] were the sole justification for the control of the liquor traffic, there would be great force in the objection that it runs counter to fundamental principles of individual liberty; strong reliance is therefore placed upon the ulterior dangers to the community at large from the existence of intemperance in its midst.

Freund at 192.

27 Commonwealth v. Campbell, 133 Ky. 50, 117 S.W. 383 (1909); City of Carthage v. Block, 139 Mo. App. 386, 123 S.W. 483 (1909); State v. Williams, 146 N.C. 618, 61 S.E. 61 (1908); State v. Gilman, 33 W. Va. 146, 10 S.E. 283 (1889). In an annotation of Commonwealth v. Campbell, supra, it is stated:

In accordance with the view expressed in the reported case, it has been held generally that the mere possession of intoxicating liquor, kept for one's own use, is not inherently injurious to the health, morals, or safety of the public; and, therefore, that legislation prohibiting such keeping in possession is not a legitimate exercise of police power, but, on the contrary, is an abridgment of the privileges and immunities of the citizen without any legal justification, and, as such, void. Eidge $v$. Bessemer, 164 Ala. 599, 51 So. 246, followed in French $v$. Birmingham, (Ala.) 51 So. 254; Sullivan $v$. Oneida, 61 Ill. 242; State $v$. McIntyre, 139 N.C. 599, 52 S.E. 63; State $v$. Williams, 146 N.C. 618, 14 Ann. Cas. 562, 61 S.E. 61, 17 L.R.A.N.S. 299; Titsworth $v$. State, 2 Okla. Crim. 268, 101 Pac. 288; State $v$. Gilman, 33 W. Va. 146,10 S.E. 283,6 L.R.A. 847.

19 ANN. CAS. 163.

28 Commonwealth v. Campbell, 133 Ky. 50, 59-61, 117 S.W. 383, 386-7 (1909).

29133 Ky. 50, 117 S.W. 383 (1909). 
[T] he question of what a man will drink, or eat, or own, provided the rights of others are not invaded, is one which addresses itself alone to the will of the citizen. It is not within the competency of government to invade the privacy of a citizen's life and to regulate his conduct in matters in which he alone is concerned, or to prohibit him any liberty the exercise of which will not directly injure society. ${ }^{30}$

And the court in City of Carthage $v$. Block, ${ }^{31}$ while not citing Mill, echoed his criterion:

If the ordinance under consideration had been ... limited to the streets and alleys and public places, it could be upheld as being reasonable... [ $\mathrm{T}]$ o say that the city may prohibit drinking in places not open to the public ... would be to allow it to encroach upon the private rights which all governments should hold sacred ...32

The leading Supreme Court decision of the period, Mugler v. Kansas, $^{33}$ held that Kansas could prohibit the manufacture of liquor for one's own use, but on the grounds that the state had found it to be a measure necessary to the adequate enforcement of other legislation against public sale and manufacture. ${ }^{34}$ Indeed, the Court stated:

The argument made ... is, that in the implied compact between the State and the citizen certain rights are reserved by the latter, which are guaranteed by the constitutional provision protecting persons against being deprived of life, liberty, or property, without due process of law, and with which the State cannot interfere; that among those rights is that of manufacturing for one's use either food or drink; and that while, according to the doctrines of the Commune, the State may control the tastes, appetites, habits, dress, food, and drink of the people, our system of government, based upon the individuality and intelligence of the citizen, does not claim to control him, except as to his conduct to others, leaving him the sole judge as to all that only affects himself.

It will be observed that the proposition, and the argument made in support of it, equally concede that the right to manufacture drink for one's personal use is subject to the condition that such manufacture does not endanger or affect the rights of others. If such manufacture does prejudicially affect the rights and interests of the community, it follows, from the

$80 \mathrm{Id}$. at 58,117 S.W. at 385 .

31199 Mo. App. 386, 123 S.W. 483 (1909).

32 Id. at $392-3,123$ S.W. at 485.

33123 U.S. 623 (1887).

34123 U.S. 623, 662 (1887). 
very premises stated, that society has the power to protect itself, by legislation, against the injurious consequences of that business. ${ }^{35}$

While the Supreme Court was granting discretion to state legislatures, certain state courts were equating Mill's principle with constitutional limitations on the police power, at least as concerns liquor. In so doing the state courts, in order to avoid a conflict with Mugler, were developing a distinction between possession of liquor with intent to sell and possession of liquor for one's own use. ${ }^{36}$

At this time the prohibition movement was growing into national proportions. The prohibitionists characterized intemperance as evil not only in the individual concerned but also as a danger affecting all those around him..$^{37}$ In an atmosphere of increasing public opposition to the sale of intoxicating liquors, the Supreme Court in Crane $v$. Campbell" extended its "enforcement-of-other-regulations" doctrine to

35 Id. at 660 . The Mugler decision as a whole was taken by several later courts to stand for the proposition that, in the absence of a reasonable relation to the public welfare, a statute would be void. American Motorcycle Ass'n v. Davids, 11 Mich. App. 35I, 355, 158 N.W.2d 72, 74 (1968); State v. Gilman, 33 W. Va. 146, 149, 10 S.E. 283, 284 (1889).

30 State v. Williams, I46 N.C. $618,633,61$ S.E. 61,66 (1908):

Viewed from any possible point of view, the sole question is, what, if any, relation has the act of carrying into the county of Burke, in any one day, more than onehalf gallon of vinous, spiritous or malt liquors, in said county, to the sale of such liquor? In view of the numerous uses to which that quantity of such liquor may be put other than selling, and of the improbability of any reasonable person carrying into the county the prohibited quantity for sale, can it be insisted that any such real or substantial relation to the sale exists?

State v. Gilman, 33 W. Va. 146, 151, 10 S.E. 283, 285 (1889):

$A$ very different question would be presented if the act had made it unlawful for any person to keep intoxicating liquors in his possession ... for the purpose of selling it, or as a device to evade the revenue laws.

In Gilman the defendant had less than five gallons, and in Williams, though unspecified, the quantity seemed to be not much over the half-gallon cutoff point; in Mugler the defendant was running a brewery.

37 See, e.g., W.F. Crafts, Why Dry? (1918); A. Sinclatr, Prohibition 50-74 (1965); Proceedings of the Sixteenth National Convention of the Anti-Saloon League of America 19, 56-63, 68, 73, 84-87, 215-8 (1915); Proceedings of the Fifteenth National Convention of the Anti-Saloon League of AMerica 28-29, 30-31, 239-46 (1913). The House of Representatives set aside December 22, 1914 for debate on the passage of the eighteenth amendment. 52 CoNG. REc. 495-616 (1914). A comprehensive list of the "dangers" of alcohol to society was presented by Rep. Hobson. Id. at 604-7. Random samples of other comments include:

It is charged against the liquor traffic that it is responsible for 50 per cent of the crime in the United States.

Id. at 497 (Rep. Campbell); and:

It is almost universally admitted that the liquor business is the greatest evil in existence; that it is the greatest source of crime, immorality, disease, idleness, poverty, and national waste; and that it is highly detrimental and injurious to the social, economic, and moral welfare of our citizens.

Id. at 517 (Rep. Morgan).

For an anti-prohibition view, see C. Darrow, The Prohibition Mania (1927).

38245 U.S. 304 (1917). See 2 A.L.R. 1085 (1919). 
include the prohibition of the possession of liquor for one's own use. This was later extended in Samuels v. McCurdy ${ }^{39}$ also to encompass the possession of liquor legally obtained before prohibition, where the Court justified the legislation in these terms:

It is obvious that if men are permitted to maintain liquor in their possession, though only for their own consumption, there is danger of its becoming accessible to others. Legislation making possession unlawful is therefore within the police power of the States as a reasonable mode of regulating the evils of drunkenness. ${ }^{40}$

The philosophy of the earlier state decisions on constitutional guarantees akin to Mill's precepts was voiced in the dissenting opinion, which attacked the majority's acceptance of the purported relation between private consumption and the public welfare.41

This shift in judicial attitude toward liquor legislation is not readily explained in the context of Mill's principle. It might be argued that the courts were not rejecting Mill's philosophy, but were merely accepting legislative findings of fact and recognizing the then current popular feeling that individual consumption of liquor did have a substantial effect upon the community. It might also be suggested that although Mill's criterion was accepted in certain categories of conduct, it was not accepted in others, and that the public conception of liquor shifted from the former categories to the latter. For example, if Mill's principle were not accepted with regard to the enforcement of morality, the strong popular tide to classify the consumption of liquor as immoral would merely extend the police power with regard to liquor without affecting the limitations in those categories of behavior considered amoral. Finally it might be argued that the decisions were a frontal assault on Mill's criterion and that they established the state's right to interfere in private conduct as long as no explicit constitutional rights were infringed.42 This last result has never been suggested by later courts as a broad principle.

39267 U.S. 188 (1925).

$40 I d$. at 198 (emphasis supplied).

$41 \mathrm{Id}$. at 202-3. Among later cases following the majority position are: Young v. State, 167 Ga. 165, 144 S.E. 726 (1928); Stepp v. State, 202 Miss. 725, 32 So. 2d 447 (1947), suggestion of error overruled, 202 Miss. 725, 33 So. 2d 307 (1948).

42 Bruce, The Private Stock of Liquor and the Inherent Right of Self-Destruction, 20 ILL. L. REv. 757 (1926). This early commentator, in discussing Samuels v. McCurdy, dealt directly with the question implicitly posed by this comment-the relation, if any, between Mill's philosophy and constitutional limitations on police power. He concluded, in effect, that the public welfare was so broad as to encompass all health and safety measures without restriction, and Mill's philosophy has become obsolete. Bruce at 760-3. 


\section{B. A Contemporary Debate: Motorcycle Helmets}

The majority of states in recent years have required the use of safety helmets by motorcyclists and their passengers. ${ }^{43}$ On first impression this helmet requirement appears to be solely to reduce possible head injuries to the motorcycling community and hence to be an exercise of state power over individual conduct which is inconsistent with Mill's criterion. Those affected by such legislation have vigorously argued Mill's principle to the courts with varying results. Two of the statutes were invalidated; ${ }^{44}$ and three more were temporarily under a cloud before appellate courts reversed. ${ }^{45}$ But the majority of courts have upheld the statutes as a valid exercise of the police power. ${ }^{46}$

Professor Bruce based his conclusion for the scope of the police power on the landmark case of Holden v. Hardy, 169 U.S. 366 (1898), which upheld a statute limiting the employment of minors to eight hours a day. Bruce at 769. It is quite true, as he asserted, that this decision recognized the state's concern for the individual and particular classes as opposed to society in general. In this sense the decision greatly expanded the definition of what constitutes the public welfare. On this point Professor Bruce deprecated the decision in In re Morgan, 58 P. 1071 (Colo. 1899), which voided a somewhat similar statute. Bruce at 769. However, one crucial difference must be pointed out between the two casesthe statute in Holden $v$. Hardy was enforced against the employer, while that in In re Morgan was enforced against the employee. Mill himself would not deny the states' power to enact legislation acting on employers for the protection of employees, although he might differ on the economic wisdom of such legislation. Mirl at 203. Professor Bruce also takes the unusual stand that the passage of the eighteenth amendment indicated that the prohibition of the consumption of liquor was previously constitutional. Bruce at 774. By definition, amendments are usually passed to change the Constitution.

But while it is conceded that the scope of the public welfare and the reach of the police power have been greatly expanded in the last century, it does not necessarily follow that the distinction between government action bearing on others than those to be protected and action bearing directly on those to be protected has been abolished. In essence, the early commentator seems to have confused Mill's philosophy on the wisdom of certain state action with his philosophy on the limitations on state action. Bruce at 767-9. The latter philosophy did not concern the question of what constituted the public welfare but rather the question of state interference with conduct which did not substantially affect other persons. While the questions are related as discussed previously, they are not identical. The force of Mill's philosophy on state limitations remains intact even as the scope of the public welfare increases with the growing complexity and interaction of society.

Nor has Professor Bruce's certainty been shared by the courts. The latest series in the dialogue, the motorcycle helmet cases, illustrates a sharp division on the subject among the state courts even now. See text at notes 43-53 infra. It seems safe to say that, even if Mill is not in the spotlight, his influence is still felt.

43 Comment, Constitutionality of Mandatory Motorcycle Helmet Legislation, 73 Dick. L. REv. 100, 101 n.8 (1969) (listing statutes).

44 People v. Fries, 42 Ill. 2d 446, 250 N.E.2d 149 (1969); American Motorcycle Ass'n v. Davids, 11 Mich. App. 351, 158 N.W.2d 72 (1968), noted in 18 Drake L. REv. 124 (1968), 67 Mick. L. REv. 360 (1968), 71 W. VA. L. REv. 191 (1969), and 1969 Wis. L. REV 320.

45 State v. Eitel, 227 So. 2d 489 (Fla. 1969) (reversing lower court); Everhardt v. City of New Orleans, 208 So. $2 d 423$ (La. Ct. App. 1968), aff'd mem., 252 La. 269, 210 So. 2d 508 (1968), rev'd, 253 La. 285, 217 So. 2d 400 (1968) (4-3 decision), cert. denied, 395 U.S. 212 
The strict numerical box score, however, scratches only the surface. Most of the majority courts have displayed a marked hesitance explicitly to reject Mill, but have instead attacked the assumption that the helmet requirement is solely for the benefit of the wearer. The strongest rationale proferred is that given dense, high-speed traffic conditions, helmets protect the cyclist from stones or other objects propelled by the wheels of other vehicles and thus prevent accidents involving others which might result if the cyclist were to lose control when hit by such a projectile. ${ }^{47}$ Other considerations raised include the desire to stay the cost of insurance ${ }^{48}$ and the fear that severe head injuries may cause the cyclist and his dependents to become public charges..$^{49}$ This last argument was refuted by a Michigan court which echoed Mill's underlying concern:

The Attorney General further contends that the State has an interest in the "viability" of its citizens and can legislate to keep them healthy and self-supporting. This logic would lead to unlimited paternalism. ${ }^{50}$

(1969); People v. Carmichael, 53 Misc. 2d 584, 279 N.Y.S.2d 272 (Genesee County Ct. Spec. Sess. 1967), rev'd, 56 Misc. 2d 388, 288 N.Y.S.2d 931 (Genesee County Ct. 1968). See People v. Smallwood, 52 Misc. 2d 1027, 277 N.Y.S.2d 429 (Monroe County Ct. Spec. Sess. 1967) (voided statute as infringement of freedom to dress as one pleases, but decision not appealed by prosecutor).

46 State v. Burzycki, 37 U.S.L.W. 2448 (Conn. Cir. Ct.), appeal denied, 252 A.2d 312 (Conn. 1969); Commonwealth v. Howie, 238 N.E.2d 373 (Mass. 1968), cert. denied, 393 U.S. 999 (1968), noted in 36 TENN. L. Rev. 405 (1969); State v. Mele, 103 N.J. Super. 353 , 247 A.2d 176 (Hudson County Ct. 1968); State v. Krammes, 105 N.J. Super. 345, 252 A.2d 223 (Super. Ct.), cert. denied, 54 N.J. 257, 254 A.2d 800 (1969); Kraft v. New York, 38 U.S.L.W. 3134 (N.Y. City Ct. Onondaga County), cert. denied, 396 U.S. 24 (1969); People v. Newhouse, 55 Misc. 2d 1064, 287 N.Y.S.2d 713 (Ithaca City Ct. 1968); People v. Schmidt, 54 Misc. 2d 702, 283 N.Y.S.2d 290 (Erie County Ct. 1967), appeal dismissed, 23 N.Y.2d 686, 243 N.E.2d 153, 295 N.Y.S.2d 936 (1968); People v. Bielmeyer, 54 Misc. 2d 466, 282 N.Y.S.2d 797 (Buffalo City Ct. 1967); State v. Anderson, 3 N.C. App. 124, 164 S.E.2d 48 (1968), aff'd, 275 N.C. 168, 166 S.E.2d 49 (1969); State v. Odegaard, 165 N.W.2d 677 (N.D. 1969); State v. Craig, 19 Ohio App. 2d 29, 249 N.E.2d 75 (Ct. App. 1969); State v. Fetterly, 456 P.2d 996 (Ore. 1969); State ex rel. Colvin v. Lombardi, 241 A.2d 625 (R.I. 1968); Ex parte Smith, 441 S.W.2d 544 (Tex. Crim. App. 1969); Bisenius v. Karns, 42 Wis. 2d 42, 165 N.W.2d 377, cert. denied, 395 U.S. 709 (1969); see also cases cited supra note 32. Comment, State's Power to Require an Individual to Protect Himself, 26 WASH. \& LEE L. REv. 112 (1969).

47 E.g., State v. Fetterly, 456 P.2d 996 (Ore. 1969).

48 State v. Anderson, 3 N.C. App. 124, 128, 164 S.E.2d 48, 50 (1968), aff'd, 275 N.C. 168, 166 S.E.2d 49 (1969).

It is interesting to speculate whether the pooling of risks in itself would make conduct, otherwise protected under Mill's criterion, subject to regulation.

49 People v. Newhouse, 55 Misc. 2d 1064, 1065-6, 287 N.Y.S.2d 713, 715 (Ithaca City Ct. 1968).

50 American Motorcycle Ass'n v. Davids, 11 Mich. App. 351, 158 N.W.2d 72, 75 (1968). A New York Court reasoned:

[T] can be argued that the statute here questioned affects public welfare because 
Another court, to counter the cyclist's reliance on Mill, itself referred to Mill to support its conclusion that the cyclist's death would have a substantial effect on others:

The unwilling cyclists must obey this law. We admire John Stuart Mill's Essay on Liberty, which their counsel cite to persuade us that the State of Florida has unconstitutionally infringed Eitel's and Thompson's right to be let alone. But Mill said there that "no person is an entirely isolated being; it is impossible for a person to do anything seriously or permanently hurtful to himself without mischief reaching at least to his near connections, and often far beyond them." If he falls we cannot leave him lying in the road. The legislature may constitutionally conclude that the cyclist's right to be let alone is no more precious than the corresponding right of ambulance drivers, nurses and neurosurgeons. ${ }^{51}$

Several of the courts did, however, explicitly reject Mill with regard to the prevention of physical harm, ${ }^{52}$ while some of the more hesitant

if a person suffers injury that could have been avoided by wearing a protective helmet, that person will perhaps become a public charge because of a disabling injury and that those who have been dependent upon that person for support may also become a public charge. The possibility and even likelihood of this happening cannot be denied. If a statute required every person to refrain from smoking there could be no serious argument that many persons would be spared crippling illnesses that cause premature disability and death. If a statute required every person to retire to bed by 10:00 p.m. every evening it would probably benefit the general health of many citizens. A court cannot say as a matter of law that there is no public benefit from a statute requiring motorcyclists to wear a protective helmet, or a statute requiring all persons to refrain from smoking, or a statute requiring all persons to retire to bed by 10:00 p.m. every evening.

To state this argument and concede that it has weight does not decide the issue. If the fact that this argument has validity were taken to decide a question such as presented by this case, then it would justify almost any rule imposed by the legislature, for our society is so complex today that there are very few things that cannot be said to affect some other person or the public treasury. If this argument were to decide questions such as presented by this case, then the hypothetical statute requiring people to go to bed early would be valid. But such an argument does not decide the question but merely poses one factor to be considered with other factors.

The statute challenged in this case has the direct effect of protecting the physical well being of the person who is subject to the mandate of the statute, and the indirect effect of protecting other persons from the burdens that might result from the death or disability of the person subject to the mandate; the direct effect is to safeguard the motorcyclist and the indirect effect the prevention of the motorcyclist and his dependents from becoming public charges.

As the police power is understood by this court it justifies the regulation of the conduct of one person because of the effect of that conduct upon other persons. Therefore the police power does not justify the statute on the basis of the direct effect alone. Is the indirect effect such that the police power authorizes the statute?

In the opinion of this court it is not.

People v. Carmichael, 53 Misc. 2d 584, 588, 279 N.Y.S.2d 272, 277 (Genesee County Ct. Spec.

Sess. 1967), rev'd, 56 Misc. 2d 388, 288 N.Y.S.2d 931 (Genesee County Ct. 1968).

51 State v. Eitel, 227 So. 2d 489, 491 (Fla. 1969).

52 State v. Mele, 103 N.J. Super. 353, 355, 247 A.2d 176, 178 (Hudson County Ct. 1968)

("the state has an interest in attempting to protect people from the consequences of their 
only thinly veiled their rejection. ${ }^{53}$ But despite these latter cases, it does appear that Mill's precepts exert a restraining influence even on those courts which disagree with the cyclists, especially when the disagreement goes to the application and not to the precepts themselves. To these courts the main difficulty is in drawing the line between conduct affecting others and conduct which does not. As in the liquor cases, the line is not drawn at the same point by all courts.

\section{G. Private Obscenity: Overtones of Mill?}

The Supreme Court has been consistent in denying first amendment protection to obscenity, although the definition of obscenity has been less than crystal clear. ${ }^{54}$ In Stanley $v$. Georgia ${ }^{55}$ however, the Court, while reiterating its former denials of protection to obscenity, held that the possession of obscenity for personal use and consumption was constitutionally beyond regulation or prohibition by the state. Although the decision was grounded on freedom of speech, the earlier unequivocal rejection of obscenity as protected speech seems to indicate that the Court was influenced by principles akin to Mill's:

For also fundamental is the right to be free, except in very limited circumstances, from unwanted governmental intrusions into one's privacy....

These are the rights that appellant is asserting in the case before us. $\mathrm{He}$ is asserting the right to read or observe what he pleases-the right to satisfy his intellectual and emotional needs in the privacy of his own home. ${ }^{56}$

The distinction made by the Court is very similar to the distinction made in the early liquor cases between possession for sale and possession for private use. ${ }^{57}$ Indeed, the Court explicitly rejected the contention (which was accepted with respect to liquor in Mugler $v$. Kansas ${ }^{58}$ ) that

own carelessness"); People v. Carmichael, 56 Misc. 2d 388, 390, 288 N.Y.S.2d 931, 935 (Genesee County Ct. 1968) (state's interest in maintaining healthy, robust citizens).

53 People v. Newhouse, 55 Misc. 2d 1064, 1065-6, 287 N.Y.S.2d 713, 715 (Ithaca City Ct. 1968) (state's interest in keeping citizens from becoming public charges); State ex rel. Colvin v. Lombardi, 241 A.2d 625, 627 (R.I. 1968).

54 Ginzburg v. United States, 383 U.S. 463 (1966); Roth v. United States, 354 U.S. 476 (1957).

55 394 U.S. 557, 563 (1969).

$58 \mathrm{Id}$. at 549 .

67 None of the statements cited by the Court in Roth for the proposition that "this Court has always assumed that obscenity is not protected by the freedoms of speech and press" were made in the context of a statute punishing mere private possession of obscene material; the cases cited deal for the most part with the use of the mails to distribute objectionable material or with some form of public distribution or dissemination.

394 U.S. 557, 560 (1969).

88123 U.S. 623 (1887), discussed in text at notes 33-35 supra. 
prohibition of the possession of obscenity is a necessary incident to statutory schemes prohibiting distribution. ${ }^{59}$ The Court also rejected not only the assertion that exposure to obscenity may lead to crimes of sexual violence, but also the relevance of such an assertion to controlling the private consumption of ideas and information. ${ }^{60}$

The decision itself was quite narrow, perhaps out of reluctance to give broad scope to the principles implicit in the opinion. But it does suggest that in analogous cases the Court might consider an argument based on Mill's criterion, especially if there is a particular constitutional clause on which to pin the decision.

\section{Some Reflections on Mill's Influence on the Courts}

Several pervasive considerations underlie the judicial reaction in the three areas discussed above, and it is to these considerations that the discussion will now turn.

\section{A. Deference to Legislative Findings of Fact}

As noted above, ${ }^{61}$ one problem in analyzing courts' reaction to Mill's principle is the frequent deference shown to the legislative process by the courts. State legislatures in passing measures for the public welfare have traditionally exercised a fact-finding role, whether explicit or implicit, in determining what constitutes the public welfare and what means are reasonable to achieve the desired goal. If a legislature finds that certain conduct is dangerous to the public welfare and proscribes such conduct, and if the courts defer to the legislature without questioning the validity of such finding, an individual defendant is precluded from successfully raising an argument analogous to Mill's.

This process of deference to the legislature's fact finding is exemplified by decisions upholding statutes proscribing the possession and use of certain drugs. ${ }^{62}$ While advocates of these drugs protest either that the use of the drugs is not harmful, or if harmful, then only to the user, the factual nature of this protest is usually rejected by legislatures which proclaim the commonly held conception that the very nature of drug addiction predisposes the user to serious forms of crime against others, that the use of milder drugs eventually leads to addiction to more

59394 U.S. 557, 563 (1969).

$60 \mathrm{Id}$. at 567.

61 See text at notes 21, 34-35, 41 supra.

62 See, e.g., Borras v. State, 229 So. $2 d 244$ (Fla. 1969); Commonwealth v. Leis, 243 N.E.2d 898 (Mass. 1969); People v. Victor, 62 Cal. 2d 280, 398 P.2d 391, 42 Cal. Rptr. 199 (1965); People v. Aguiar, 257 Cal. App. 2d 597, 65 Cal. Rptr. 171 (1968), cert. denied, 393 U.S. 970 (1968); People v. Glaser, 238 Cal. App. $2 d$ 819, 48 Cal. Rptr. 427 (1965). 
potent narcotics, and that a person under the influence of drugs is dangerous to those around him. ${ }^{63}$ The validity of these common presumptions may be questioned, but if found by the legislature, there is little question that they present sufficient basis for the exercise of the police power, and the courts usually do defer to such legislative findings concerning drugs. ${ }^{64}$

This deference to the legislature's fact finding was evidenced to a certain degree in the liquor cases as the influence of the temperance lobby made itself felt in the then popular conception of liquor as undermining the fabric of society. ${ }^{65}$ It was also evidenced in several of the motorcycle helmet decisions. ${ }^{66}$ Other examples include determinations of what are contagious diseases for quarantine purposes, ${ }^{67}$ what are proper conditions for the imposition of curfews, ${ }^{68}$ and what are reasonable means of preventing illegitimate births. ${ }^{69}$

The result of this deference to the legislature is that where the issue of socially harmless conduct may be presented, it is possible for courts to avoid it by deference to insubstantial or inaccurate legislative findings of fact. This, of course, raises the question of the power of the courts to overrule patently insubstantial or inaccurate findings of fact, but the

63 See authorities cited note 62 supra. Indeed, in a Mill-oriented opinion, a lower court stated:

There are statutes that regulate a citizen in matters that affect his own health.

For example, the citizen is restricted in the use of alcohol and narcotics. However

it must be noted such restriction is not the exercise of the police power to make

a citizen maintain himself in a state of physical and mental well being so that other persons may not be deprived of sharing in the fruits of his good health; it is the exercise of the police power to protect other persons from the harmful conduct of citizens whose behavior toward others is affected by the use of alcohol or narcotics.

People v. Carmichael, 53 Misc. 2d 584, 589-90, 279 N.Y.S.2d 272, 278 (Genesee County Ct. Spec. Sess. 1967) (voiding motorcycle helmet requirement), rev'd, 56 Misc. 2d 388, 288 N.Y.S.2d 931 (Genesee County Ct. 1968). However, an early decision, Ah Lim v. Territory, 1 Wash. St. 156, 24 P. 588 (1890), upheld a statute prohibiting the smoking or inhaling of opium on the grounds that any detriment to the opium user would be visited upon the public in general by the user becoming a public charge either as a pauper or as an imbecile.

For the opposing view, see Note, The California Marijuana Possession Statute: An Infringement on the Rights of Privacy or Other Peripheral Constitutional Rights?, 19 Hastincs L.J. 758 (1968).

64 See authorities cited note 62 supra.

65 See note 37 supra and accompanying text.

60 See, e.g., State v. Anderson, 3 N.C. App. 124, 126, 164 S.E.2d 48, 50 (1968), aff'd, 275 N.C. 168, 166 S.E.2d 49 (1969); Ex parte Smith, 441 S.W.2d 544 (Tex. Crim. App. 1969).

67 Compagnie Francaise de Navigation a Vapeur v. State Bd. of Health, 186 U.S. 380 (1902); Ex parte Fowler, 85 Okl. Crim. 64, 184 P.2d 814 (1947).

68 See, e.g., State v. Boles, 5 Conn. Cir. Ct. 22, 240 A.2d 920 (1967).

o9 Levy v. State, 192 So. 2d 193 (La. Cir. Ct. App. 1966), rev'd, 391 US. 68 (1968). For a discussion of the legislative purpose in this case, see Krause, Legitimate and Illegitimate Offspring of Levy v. Louisiana-First Decision on Equal Protection and Paternity, 36 U. Chr. L. REv. 338, 346-7 (1969). 
crux of the problem for present consideration is what the courts' deference signifies. It may indicate literal deference, or it may be a mere ploy for rejecting Mill's criterion and for upholding statutes which the courts deem constitutional even if the statutes are solely for the protection of the person prosecuted. This latter may be especially true if the court itself suggests what it considers to be the implicit finding of fact and purpose of the legislature. ${ }^{70}$ Whether such evasion of the issue exists in a particular case is, of course, a highly speculative inquiry into the circumstances of that case, but it is nevertheless important to acknowledge the ever present opportunity for such judicial side-stepping of the issue raised by Mill's principle.

\section{B. Substantiality of Relation to Public Welfare}

Theoretically there is very little, if any, individual conduct that does not affect other people. Even acts done in absolute privacy with no immediately harmful results can be said to mold certain personality traits which will sooner or later manifest themselves in social relations. Hence, the issue is how the courts have dealt with the regulation of conduct which does not substantially affect others. Substantiality involves the probability of effect as well as the degree to which the other persons are affected.

The meaning of "substantial" is by its very nature ambiguous. A broad usage of the word would dilute, if not completely negate, any individual rights falling within the scope of Mill's principle. The classic example of such dilution is the argument that the state has a direct and valid interest in every aspect of an individual's well-being since his lack of well-being might diminish the public economic output. ${ }^{71}$ This type of dilution magnifies the impact of individual conduct on society as a whole and would seemingly justify state regulation of every aspect of human behavior.

Another type of dilution occurs when probabilities are magnified to find a substantial relation between an individual's conduct and its possible effect on others. An example of this type of dilution would be an argument in support of the required use of seat belts to the effect that the ejection of passengers in an automobile collision is apt to cause secondary accidents by vehicles attempting to avoid the ejected passengers. Whether the courts actually believe that such causal chains

70 See, e.g., State ex rel. Colvin v. Lombardi, 241 A.2d 625 (R.I. 1968).

71 This is an extension of the argument that the state must protect the individual from himself so that he does not become a public charge. People v. Carmichael, 56 Misc. 2d 388, 390, 288 N.Y.S.2d 931, 935 (Genesee County Ct. 1968); People v. Newhouse, 55 Misc. 2d 1064, 1065-6, 287 N.Y.S.2d 713, 715 (Ithaca City Ct. 1968); Ah Lim v. Territory, 1 Wash. St. 156, 164, 24 P. 588, 590 (1890) (discussed in note 63 supra). 
are substantial is open to question. It may well be that such causal chains are employed only to camouflage a rejection of Mill's criterion in certain cases without resorting to an explicit statement by which the courts may not wish to be bound.

But no matter what definition is given to the term "substantial," the fact that the question is always one of degree raises an inherent difficulty with Mill's principle-where does one draw the line and what factors are relevant in drawing that line? One approach would consider only the state's interest in protecting others without regard to the degree of infringement on the individual's freedom of conduct. This yardstick is implicit in Mill's reliance on personal eccentricities as examples of the type of individual conduct to which his criterion would apply. Under this approach the slight inconvenience to the motorcyclist $^{72}$ would be equivalent to the much greater restrictions which result from the prohibition of certain religious practices, ${ }^{73}$ at least as regards the individual's interest.

An alternative approach would balance the state's interest against the individual's interest in freedom of conduct. This approach was used explicitly in several of the motorcycle helmet cases. ${ }^{74} \mathrm{~A}$ similar balancing seems to have occurred in Stanley $v$. Georgia. The state's interest is the same in prohibiting the possession of obscenity both for sale and for private use; ${ }^{75}$ however, the right of the individual to receive ideas, regardless of their social worth, was deemed more fundamental than the right to propagate those ideas. ${ }^{76}$

Regardless of which of the above approaches is taken, the problem of where to strike the balance remains. Popularly elected legislatures seldom exercise the police power in a blatantly offensive manner, ${ }^{77}$

72 Bisenius v. Karns, 42 Wis. 2d 42, 53, I65 N.W.2d 377, 383, cert. denied, 395 U.S. 709 (1969) (personal liberty of cyclist not inconsequential).

73 For example, the prohibition of the use of snakes in religious ceremonies, State v. Massey, 229 N.C. 734, 51 S.E.2d 179 (1949), appeal dismissed sub nom. Bunn v. North Carolina, 336 U.S. 942 (1949); Lawson v. Commonwealth, 291 Ky. 437, 164 S.W.2d 972 (1942); Harden v. State, 188 Tenn. 17, 216 S.W.2d 708 (1948); or the prohibition of the use of peyote, People v. Woody, 61 Cal. 2d 716, 394 P.2d 813, 40 Cal. Rptr. 69 (1964) (holding the prohibition unconstitutional as applied to members of the Native American Church).

74 See, e.g., State v. Fetterly, 456 P.2d 996, 997 (Ore. 1969).

75 See L. Henkin, Morals and the Constitution: The Sin of Obscenity, 63 Colum. L. REv. 391 (1963).

78 The Court stated: "This right to receive information and ideas, regardless of their social worth, is fundamental to our society." 394 U.S. 557, 564 (1969) (emphasis added).

77 For example, a requirement that every person receive a minimum of eight hours sleep a night or that every person refrain from consuming beyond a certain number of calories per day, regardless of problems of enforcement, would seem clearly unconstitutional. See People v. Carmichael, 53 Misc. 2d 584, 589, 279 N.Y.S.2d 272, 277 (Genesee County Ct. Spec. Sess. 1967), rev'd, 56 Misc. 2d 388, 288 N.Y.S.2d 931 (Genesee County Ct. 
however, and most contested regulations of conduct will not clearly fall on one side of whatever line is drawn. Hence, if the balancing is to retain any vitality, it will require that courts be willing to examine the underlying rationale of the legislatures.

\section{A Sliding Scale}

The states have long deemed it within their power to punish deviation from conventional sexual mores. ${ }^{78}$ Except for statutes forbidding acts of force, openly public displays, and conduct involving minors (all of which Mill concedes to be the valid object of regulation ${ }^{79}$ ), proscription of such deviation appears solidly to contradict Mill's tenets. However, Lord Devlin, one of the chief proponents of the legal enforcement of morality, avers that such proscription is vital to the existence of society in that society is held together by a pervasive moral fabric and a weakening of that fabric would cause the breakdown of societal institutions. ${ }^{80}$ The validity of this proposition has been questioned in general, ${ }^{81}$ and its applicability to private acts within the framework of marriage is even more dubious.

There are still many statutes proscribing a vast range of sexual behavior. ${ }^{82}$ The origin of these statutes is traceable to the influence of

1968). In light of recent efforts to reduce cigarette smoking, it is interesting to speculate whether cigarette smoking is more analogous to the preceding hypotheticals than to the use of marijuana.

78 People v. Roberts, 256 Cal. App. 2d 488, 64 Cal. Rptr. 70 (1967); Rhinehart v. Washington, 70 Wash. 2d 649, 424 P.2d 906 (1967), cert. denied, 389 U.S. 832 (1967). For an excellent view of some of the statutes on the books in fairly recent times, see Note, Post-Kinsey, Voluntary Sex Relations as Criminal Offenses, 17 U. CHI. L. REv. 162 (1949). On homosexuality, see Cantor, Deviation and the Criminal Law, 55 J. CRIM. L. 441 (1964); Project, The Consenting Adult Homosexual and the Law: An Empirical Study of Enforcement and Administration in Los Angeles County, 13 U.C.L.A.L. REv. 643 (1966); Note, Private Consensual Homosexual Behavior: The Crime and Its Enforcement, 70 YALE L.J. 623 (1961).

79 Acts of force and openly public displays obviously infringe upon the rights of others; as to minors, see MiL.. at 96.

80 Sir Patrick Devlin, The Enforcement of Morals 9-13 (1965).

81 Hart, Social Solidarity and the Enforcement of Morality, 35 U. CHI. L. REv. I (1967). See also H.L.A. Hart, The MoraltTy of the Criminal Law (1965); H.L.A. Hart, LAw, LIBERTY AND MORALITY (1963). For discussion of Devlin, Hart, and Mill, see Dworkin, Lord Devlin and the Enforcement of Morals, 75 YALE L.J. 986 (1966); Symposium, The Philosophy of H. L. A. Hart, 35 U. ChI. L. Rev. 1 (1967); Comment, Private Consensual Adult Behavior: The Requirement of Harm to Others in the Enforcement of Morality, 14 U.C.L.A.L. REv. 581 (1967).

82 See, e.g., Cal. Pen. Code \& 288a (Deering 1961); Minn. STAt. ANN. § 617.14 (1964); WASH. REv. CODE ANN. \& 9.79.100 (1961); W. VA. CODE $\$$ 61-8-13 (1965). These cited statutes proscribe conduct which Kinsey described as common among married couples; the statutes do not mention any exceptions for married couples. In addition most states proscribe adultery and fornication in varying degrees, and incest and homosexuality (usually described under the phrase "crime against nature" or a similar ambiguous phrase) completely. 
religion on law and politics in the eighteenth and nineteenth centuries. ${ }^{83}$ This influence, which will be labelled the "morality effect," 84 uses secular legal institutions to proscribe conduct which offends the morals of certain groups regardless of whether the offender is a member of such groups. The morality effect is strongest when the conduct to be proscribed is most closely related to the religious principles of the majority of the population, and it diminishes the less religiously offensive the conduct becomes. ${ }^{85}$ It may or may not operate as the sole basis for a regulation of "morally offensive" conduct. The result of the morality effect is most vivid in the area of sexual mores, but it was also evident in the Prohibitionist movement which acquired a highly religious flavor. ${ }^{86}$

On the other hand, the states have seldom interfered directly with a competent ${ }^{87}$ individual's care of his personal health. ${ }^{88}$ For instance, in the much litigated field of compulsory blood transfusions to patients near death, the established rule appears to be that blood transfusions cannot be administered over a patient's refusal, no matter how urgently needed, unless minor children are involved or the patient is incompetent. ${ }^{89}$ Although the individual's right to refuse blood transfusions is upheld primarily on freedom of religion grounds, ${ }^{90}$ it is submitted that a person should also have the right to refuse medical aid solely on a conscientious basis. 91 In any event, refusal of medical aid is usually

83 See Nelson, Emerging Notions of Modern Criminal Law in the Revolutionary Era: An Historical Perspective, 42 N.Y.U.L. REv. 450 (1967).

84 Some may prefer the term "puritanism."

85 See Henkin, supra note 61 , on obscenity. Any particular conduct may itself become morally less offensive as the religious climate changes. This is seen in the policy decision to repeal some of the older sex laws. In Illinois, for example, private consensual behavior is no longer a criminal offense. Compare ILL. Rev. Stat. ch. 38, art. Il (1967), with IlL. REv. StAT. ch. 38, \& 141 (1953).

86 See, e.g., A. Sinclatr, Prohibition 75-91 (1965); Proceedings of the Sixteenth National Convention of the Anti-Saloon League of America 79-84, 84-87, 120-1 (1915); Proceedings of the Fifteenth National Convention of the ANTi-Saloon League of Ameriaa 70-76 $88-97,110-8,124-9$ (1913).

87 See note 10 supra on the care of mental incompetents.

88 See note 9 supra.

80 Jehovah's Witnesses v. King County Hosp., 278 F. Supp. 488 (W.D. Wash. 1967), aff'd per curiam, 390 U.S. 598 (1968); Application of President \& Directors of Georgetown College, 331 F.2d 1000, rehearing denied, 331 F.2d 1010 (D.C. Cir. 1964); In re Brooks' Estate, 32 Ill. 2d 361, 205 N.E.2d 435 (1965), cert. denied, 377 U.S. 978 (1966), noted in 64 Mrch. L. REv. 554 (1966); Raleigh Fitkin-Paul Morgan Memorial Hosp. v. Anderson, 42 N.J. 421, 201 A.2d 537 (1964), cert. denied, 377 U.S. 985 (1965); Erickson v. Dilgard, 44 Misc. 2d 27, 252 N.Y.S.2d 705 (Sup. Ct. 1962). See Note, The Right to Die, 18 U. FLA. L. REv. 591 (1966).

90 The patient so refusing is invariably a Jehovah's Witness. For a general background on the conflict between the Jehovah's Witnesses and medicine, see How, Religion, Medicine and Law, 3 CAN. B.J. 365 (1960).

01 A broadening of the first amendment freedom of religion guarantee to include "freedom of convictions" appears to be occurring in the realm of the Selective Service conscientious objector exemption from military duty. While the exemption is a matter of 
religiously inoffensive behavior which historically has seldom been characterized by the morality effect.

Thus, a sliding scale, with conduct having a large morality effect on one end of the spectrum and behavior with no morality effect on the other end, may partially explain the judicial reaction to challenges to regulations of conduct not substantially affecting others. At first glance this may appear to be reducible to the proposition that, if the majority feels strongly enough about a mode of behavior, restrictions will be upheld. But on closer examination, one sees that legal intrusion into private conduct frequently has religious overtones. Purely culturally deviant behavior, though often abhorred and met by social sanctions, is seldom proscribed by law. ${ }^{92}$ The morality effect, in view of the establishment clause of the first amendment, may itself present constitutional issues, but so far it has not been questioned on these grounds.

\section{Mill and the Constitution}

Mill's principle is directed primarily to limitation of the police power. Whether his criterion is actually reflected in any constitutional protection is problematical. The challenges to regulation of conduct allegedly not affecting others have been made on several grounds, but only in the liquor and motorcycle cases has Mill's criterion been invoked by the challengers. Thus, only in these two categories has the issue been squarely put, and in both situations the decisions have been mixed both as to outcome and rationale. The Supreme Court has never dealt directly with the issue, but in the relevant decisions has deferred to the judgment of the legislatures.93 ${ }^{93}$ The state courts in the early liquor

legislative grace and not of constitutional right, Clay v. United States, 397 F.2d 901, 912 (5th Cir. 1968), the Supreme Court has given a very broad interpretation to the phrases "religious training and belief" and "Supreme Being" to avoid a due process complication in the administration of the exemption. United States v. Seeger, 380 U.S. 163 (1965). The statutory exemption does not cover a non-theistic moral code, but the Court declined to deal with the question of atheistic beliefs as it was not presented. Id. at 173-4. However, a recent decision dealt directly with the issue and held for the conscientious objector applicant. United States v. Sisson, 297 F. Supp. 902 (Mass. 1969), cert. granted, 396 U.S. 816 (1969). See also United States v. Shacter, 293 F. Supp. 1057 (Md. 1968).

92 Historically various sects have been socially deprecated, but not legally persecuted, by specific statutes. The case of the Mormons was clearly within the morality effect. Reynolds v. United States, 98 U.S. 145 (1879). Linford, The Mormons and the Law: The Polygamy Cases, 9 UTAFr L. REv. 308, 543 (1964-65). More recently, uncleanliness, length of hair, and style of dress have drawn strong public disfavor, but little serious thought is given to banning such behavior per se. Indeed, several federal courts have held that a ban on long hair is unconstitutional even as applied to minors as a condition of school attendance. Breen v. Kahl, 419 F.2d 1034 (7th Cir. 1969), cert. applied for, 38 U.S.L.W. 3348 (1969); Westley v. Rossi, 305 F. Supp. 706 (D. Minn. 1969); Richards v. Thurston, 304 F. Supp. 449 (D. Mass. 1969).

83 Samuels v. McCurdy, 267 U.S. 188 (1925); Crane v. Campbell, 245 U.S. 304 (1917); 
decisions cited no specific constitutional provision, but simply held that the prohibition of the possession of liquor was an invalid exercise of the police power. ${ }^{94}$ The due process clause of the fourteenth amendment was invoked by those courts invalidating the motorcycle helmet requirement. ${ }^{95}$

The lack of reference to any specific constitutional provision in the early state liquor cases indicates a feeling of inherent limitations of the states' power, and this feeling was manifested against governments which are not confined to "enumerated powers." This suggests that there exist, at least in the opinion of some courts, underlying "inalienable" rights which remain in the people. A surfacing of this undercurrent was made explicit in the Supreme Court's decision in Griswold v. Connecticut, ${ }^{96}$ which voided a state ban on contraceptives as an unconstitutional invasion of the privacy of married couples. The Court relied on the ninth amendment and its protection of rights "retained by the people," 97 and although it seems unsettled whether the ninth amendment is a separate constitutional guarantee or merely a signpost referring back to the fifth amendment due process clause, ${ }^{98}$ Griswold does open the door to constitutional arguments based on unenumerated individual rights. Exactly what these rights are has not been explicitly detailed, but it seems certain that the list will be influenced by the writings of many of the political philosophers who have become part of the political heritage of the nation; and Mill is without doubt to be included among these writers. Indeed, Mill appears to be one of the main influences on this undercurrent of unenumerated rights as is evidenced by recurrent allusions to the "right to be let alone."99

Mugler v. Kansas, 123 U.S. 623 (1887). The denial of certiorari in several of the motorcycle helmet cases is inconclusive as to the Court's attitude. For citations, see notes 45-46 supra. 94 See authorities cited note 27 supra.

85 See authorities cited notes $44-45$ supra. The ninth amendment was also mentioned in several cases. See, e.g., American Motorcycle Ass'n v. Davids, 11 Mich. App. 351, 359, 158 N.W.2d 72, 76 (1968); Commonwealth v. Howie, 238 N.E.2d 373 (Mass.), cert. denied, 393 U.S. 99 (1968) (petition for certiorari summarized at 37 U.S.L.W. 3211).

gB 381 U.S. 479 (1965). For an excellent discussion of the case, see Symposium on the Griswold Case and the Right of Privacy, 64 Mrcr. L. REv. 197 (1965).

97 U.S. CoNST. amend. IX: "The enumeration in the Constitution, of certain rights, shall not be construed to deny or disparage others retained by the people." For a prophetic discussion on the Griswold problem, see Redlich, Are There "Certain Rights ... Retained by the People"?, 37 N.Y.U.L. REv. 787 (1962). See also Kutner, The Neglected Ninth Amendment: The "Other Rights" Retained by the People, 51 MARQ. L. REv. 121 (1967). 98 Note, The Uncertain Renaissance of the Ninth Amendment, 33 U. CHI. L. REv. 814, 828-32 (1966); see also Kauper, Penumbras, Peripheries, Emanations, Things Fundamental and Things Forgotten: The Griswold Case, 64 Micr. L. Rev. 235, $246-7$ (1965).

99 The "right to be let alone" found its strongest impetus in Justice Brandeis' famous dissent in Olmstead v. United States, 277 U.S. 438, 478 (1928):

The makers of our Constitution ... sought to protect Americans in their beliefs, 
By more traditional standards, the concept of limitations on the police power is a basic ingredient of substantive due process. ${ }^{100} \mathrm{Al}$ though the doctrine of substantive due process is amorphous and has been narrowed by post New Deal decisions, ${ }^{101}$ the limitations on the police power expounded by Mill have not been explicitly or implicitly excluded from its scope. Indeed, the theory that the ninth amendment is a signpost to the due process clause ${ }^{102}$ adds force to the argument in light of Griswold, since in many cases substantive due process conceptually is analogous to a theory of retention of unenumerated rights..$^{103}$

The first amendment ${ }^{104}$ also affords a basis for Mill's argument in proper situations. Various balancing concepts, either in freedom of speech or in freedom of religion, require as one ingredient an evaluation of the state's interest, specifically, whether the statute bears a substantial enough relation to the public health, safety, or welfare to override the restriction of first amendment claims. The absence of any substantial effect of the proscribed conduct on others in such cases would seriously detract from the state's interest in regulating such conduct. In those areas where the sole basis of legislation is the morality effect (especially sex laws), it might be argued that the enforcement of private morals is an unconstitutional establishment of religion in that such legislation imposes adherence to the religious beliefs of the majority upon those not of the same belief. ${ }^{105}$

their thoughts, their emotions and their sensations. They conferred, as against the Government, the right to be let alone-the most comprehensive of rights and the right most valued by civilized men.

This dissent was the forerunner of the present law on illegal searches and seizures. See Katz v. United States, 389 U.S. 347, 350 (1967); Mapp v. Ohio, 367 U.S. 643, 655-7 (1961); On Lee v. United States, 343 U.S. 747, 762 (1952) (Douglas, J., dissenting); Harris v. United States, 331 U.S. 145, 159 (1947) (Frankfurter, J., dissenting); Goldman v. United States, 316 U.S. 129, 141 (1942) (Murphy, J., dissenting).

The above principle has been increasingly invoked outside the search and seizure context. See, e.g., Stanley v. Georgia, 394 U.S. 557, 564 (1969); Application of President \& Directors of Georgetown College, 331 F.2d 1010, 1016-7 (D.C. Cir. 1964) (Burger, J., dissenting) (blood transfusion case); American Motorcycle Ass'n v. Davids, 11 Mich. App. $351,359,158$ N.W.2d 72, 76 (1968).

100 See Emerson, Nine Justices in Search of a Doctrine, 64 Mrck. L. REv. 219, 222-7 (1965); Comment, Substantive Due Process in the States Revisited, 18 OнIо ST. L.J. 384 (1957).

101 Professor Emerson makes the distinction between personal and economic rights. Emerson, supra note 100 , at 223-5. It is in the realm of economic rights that the doctrine has been discredited. West Coast Hotel Co. v. Parrish, 300 U.S. 379 (1937); Nebbia v. New York, 291 U.S. 502 (1934). Indeed, Justice Black's dissent in Griswold was premised on the assumption that substantive due process had been totally discredited. 381 U.S, at 511-6.

102 See note 98 supra and accompanying text.

103 See Emerson, supra note 100.

104 See notes 54-60, 89-91 supra and accompanying text.

105 Comment, Private Consensual Adult Behavior: The Requirement of Harm to Others in the Enforcement of Morality, 14 U.C.L.A.L. REv. 581, 600 (1967). 
Although the first amendment may cover only a few modes of behavior falling within Mill's doctrine, the due process clauses of the fifth and fourteenth in conjunction with the ninth amendment, would give a broad basis to the acceptance of Mill by the courts.

\section{ConcLusion}

Although Mill wrote almost a century after the Constitution was written, his philosophy on the scope of the state's power to regulate individual conduct enjoys enduring vitality. Its major impact on the American political system may be in the screening of measures in the legislative process, thus leaving only borderline application to the courts. But even in these borderline cases, Mill's impact on the judicial system is significant. While an argument based on Mill's criterion against the validity of a statute may not always be heeded by the courts, it is a respectable argument and is seldom flatly rejected. Indeed, Griswold v. Connecticut and Stanley v. Georgia, as well as several of the motorcycle helmet cases, may substantially increase the respectability of such an argument and may indicate a more willing reception by the courts. 